\title{
Ecophysiology of the Cyanobacterium Dactylococcopsis salina: Effect of Light Intensity, Sulphide and Temperature
}

\author{
By JAAP VAN RIJN* AND YEHUDA COHEN \\ H. Steinitz Marine Biology Laboratory, Hebrew University of Jerusalem, Eilat, P.O.B. 469, \\ Israel
}

(Received 24 August 1982; revised 2 March 1983)

\begin{abstract}
Dactylococcopsis salina is a planktonic gas-vacuolated cyanobacterium that forms a distinct bacterial plate at the metalimnion of Solar Lake, Sinai. Temperature, light intensity and sulphide concentration were examined as possible limiting factors determining the distribution of $D$. salina during the annual limnological cycle of Solar Lake. Both laboratory cultures and in situ samples were examined for their photosynthetic activity at a wide range of temperature, light intensity and sulphide concentrations. The cyanobacterium showed a considerable light adaptation and a capacity for photosynthetic activity at high light intensities. It also showed anoxygenic photosynthesis using $\mathrm{H}_{2} \mathrm{~S}$ as an alternative electron donor, but this activity was only $4 \%$ of oxygenic photosynthesis. Furthermore, $\mathrm{H}_{2} \mathrm{~S}$ was highly toxic to $\mathrm{D}$. salina and no $\mathrm{CO}_{2}$ photoassimilation could be detected at $\mathrm{pH} 7$ and $1 \mathrm{~mm}$-sulphide. Temperature is the primary environmental factor governing the distribution of $D$. salina in Solar Lake.
\end{abstract}

\section{INTRODUCTION}

Solar Lake is a hypersaline waterbody situated on the Sinai coast of the Gulf of Eilat. It is stratified for 10 months of the year and shows a mesothermal profile. Temperatures of up to $63.5^{\circ} \mathrm{C}$ were recorded at the metalimnion, while surface temperatures were $25^{\circ} \mathrm{C}$ during maximal stratification (Cohen et al., 1977a). The distribution of the main photosynthetic organisms has been described by Cohen et al. $(1977 \mathrm{~b})$. Gas-vacuolated organisms were not described due to inadequate sampling methods used during those investigations. Recently Walsby et al. (1983) described the occurrence of the gas-vacuolated cyanobacterium Dactylococcopsis salina; during summer holomixis of the lake this cyanobacterium can be found in small numbers throughout the whole watercolumn. With the onset of stratification of the lake a distinct layer of $D$. salina is formed just at the thermocline and this layer persists during the entire period of stratification. In 1981, maximal concentrations of 12900 cells ml ${ }^{-1}$ were found at the peak of stratification in February (Walsby et al., 1983). In spring, during partial mixing of the watercolumn, $D$. salina can be found in a wider layer extending deeper into the watercolumn. Later, with total mixing, $D$. salina is dispersed throughout the whole waterbody of Solar Lake.

Light is a major factor influencing the distribution of this cyanobacterium in Solar Lake. At the depth of occurrence of $D$. salina light intensities of up to $1000 \mu \mathrm{E} \mathrm{m}^{-2} \mathrm{~s}^{-1}$ have been measured, which is half of the ambient light intensity in this desert area. The occurrence of sulphide in the lower part of the region where $D$. salina was found to occur is another possible factor influencing the distribution of this cyanobacterium in Solar Lake. Growth of cyanobacteria in the presence of sulphide has been recorded by several investigators (Nakamura, 1937, 1938; Knobloch, 1966; Stewart \& Pearson, 1970). Cohen et al. (1975) showed sulphide to act as an alternative electron donor in the process of anoxygenic photosynthesis of the cyanobacterium Oscillatoria limnetica. Garlick et al. (1977) examined 21 strains of

Abbreviation: DCMU, 3-(3,4-dichlorophenyl)-1,1-dimethylurea. 
cyanobacteria for anoxygenic photosynthesis and showed that this is a common phenomenon in a number of cyanobacteria. Dactylococcopsis salina was not found in Solar Lake under high sulphide concentrations, yet it was found to occur at sulphide concentrations of $10 \mu \mathrm{M}$ during the night (Jørgensen et al., 1979). Sulphide may thus be a limiting factor for the occurrence of $D$. salina. In this paper we report the rate of photosynthesis of $D$. salina under various sulphide concentrations and under different light intensities. The results obtained are compared with those obtained for other non-heterocystous cyanobacteria by Garlick et al. (1977).

\section{METHODS}

Growth. The growth medium had the following composition $\left(1^{-1}\right): \mathrm{NaCl}, 125 \mathrm{~g} ; \mathrm{MgCl}_{2} .6 \mathrm{H}_{2} \mathrm{O}, 10 \mathrm{~g}$; $\mathrm{MgSO}_{4} .7 \mathrm{H}_{2} \mathrm{O}, 3.5 \mathrm{~g} ; \mathrm{KCl}, 2.5 \mathrm{~g} ; \mathrm{NaNO}_{3}, 0.75 \mathrm{~g} ; \mathrm{CaCl}_{2} .2 \mathrm{H}_{2} \mathrm{O}, 0.5 \mathrm{~g} ; \mathrm{K}_{2} \mathrm{HPO}_{4}, 15 \mathrm{mg} ; \mathrm{Na}_{2} \mathrm{CO}_{3}, 20 \mathrm{mg}$; $\mathrm{Na}_{2}$ EDTA $2 \mathrm{H}_{2} \mathrm{O}, 0.5 \mathrm{mg}$; ferric ammonium citrate, $3 \mathrm{mg}$; citric acid, $3 \mathrm{mg}$; and $0.1 \mathrm{ml}$ of the trace metal mix A5 (Stanier et al., 1971).

Cultures were grown at $37^{\circ} \mathrm{C}$ under continuous illumination provided by white fluorescent light $(2300 \mathrm{~K}, 20 \mathrm{~W})$. Light intensity was adjusted to $35 \mu \mathrm{E} \mathrm{m}^{-2} \mathrm{~s}^{-1}$ or $130 \mu \mathrm{E} \mathrm{m}^{-2} \mathrm{~s}^{-1}$ (see Results).

$\mathrm{CO}_{2}$ photoassimilation. Laboratory cultures of $D$. salina were harvested in the exponential phase of growth; in other experiments the cyanobacterium was collected by means of a peristaltic pump from the layer of maximum cell concentration in Solar Lake. Cells were washed twice in growth medium or in filtered Solar Lake water and the experiments were carried out in $3 \mathrm{ml}$ cell suspensions introduced to $5 \mathrm{ml}$ Vacutainers (Becton-Dickinson, Rutherford, N.J., U.S.A.). The cell suspension was preincubated for $1 \mathrm{~h}$ at $37^{\circ} \mathrm{C}$ under a light intensity of $35 \mu \mathrm{E} \mathrm{m}^{-2} \mathrm{~s}^{-1}$. Experiments were carried out in a temperature-controlled Perspex cell with continuous mixing. Light was provided by a $150 \mathrm{~W}$ slide projector (Braun, Germany). Various light intensities were obtained by changing the distance between the reaction vessel and the light source. After $5 \mathrm{~min}$ preincubation in the described system, $10 \mu \mathrm{l} \mathrm{NaH}{ }^{14} \mathrm{CO}_{3}$ [Amersham, U.K.; $500 \mu \mathrm{Ci}(18.5 \mathrm{MBq}) \mathrm{ml}^{-1}, 60 \mathrm{mCi}(2.2 \mathrm{GBq}) \mathrm{mmol}^{-1}$, made up in $0 \cdot 1 \mathrm{M}$-Tris buffer, $\mathrm{pH} 9 \cdot 2$ ] was added. Experiments were carried out for $5 \mathrm{~min}$ and then the cell suspension was filtered immediately through a GF/c filter (Whatman, U.K.). Filters were exposed overnight to fuming $\mathrm{HCl}$ in a desiccator. Then $5 \mathrm{ml}$ Insta Gel (Packard) was added and the radioactivity was measured using a Tri-Carb liquid scintillation counter (Packard, model 3255).

In experiments to measure the anoxygenic $\mathrm{CO}_{2}$ photoassimilation, the cells were buffered with Tricine ( $1 \mathrm{~mm}$, $\mathrm{pH} 8$ ), and DCMU ( $5 \mu \mathrm{M})$ was added. Sulphide in the form of $\mathrm{Na}_{2} \mathrm{~S}$ was added to each sample after flushing the medium with $\mathrm{N}_{2}$. In these experiments the samples were preincubated in the light for at least $2 \mathrm{~h}$ to ensure an adequate induction period for anoxygenic photosynthesis (Oren et al., 1977).

Temperature tolerance. Cells were grown in Solar Lake water. The cultures were preincubated for $10 \mathrm{~min}$ at a given temperature and then $\mathrm{NaH}^{14} \mathrm{CO}_{3}$ with a final concentration of $0.5 \mu \mathrm{Ci}(18.5 \mathrm{kBq}) \mathrm{ml}^{-1}[260 \mu \mathrm{Ci}(9.6 \mathrm{MBq})$ $\mathrm{mmol}^{-1}$ ] was added. After $30 \mathrm{~min}$ incubation, cells were filtered through $\mathrm{GF} / \mathrm{c}$ (Whatman, U.K.) filters and the filters were counted for radioactivity after being exposed overnight to $\mathrm{HCl}$ fumes. The following temperatures were used: $27^{\circ} \mathrm{C}, 35^{\circ} \mathrm{C}, 40^{\circ} \mathrm{C}, 45^{\circ} \mathrm{C}, 50^{\circ} \mathrm{C}, 55^{\circ} \mathrm{C}$ and $60^{\circ} \mathrm{C}$.

Assays. Chlorophyll $a$ and carotenoids were measured according to Strickland \& Parsons (1968). Sulphide was determined by the methylene blue method (Cline, 1969). Light intensity was measured with a Lamda photometer (QRP 361).

\section{RESULTS}

\section{Light adaptation experiments}

Two photosynthetic parameters were determined in order to define the photosynthetic activity of $D$. salina under different environmental conditions: $P_{\mathrm{m}}$, the maximal rate of photosynthesis at light saturation, and $I_{\mathrm{k}}$, the light intensity at which a photosynthetic rate numerically equal to $P_{\mathrm{m}}$ would be reached in the absence of light saturation (Talling, 1957).

A batch culture of $D$. salina grown under low light conditions $\left(35 \mu \mathrm{E} \mathrm{m}^{-2} \mathrm{~s}^{-1}\right)$ was examined for $\mathrm{CO}_{2}$ photoassimilation. The light saturation curve of this culture of $D$. salina, with a carotenoid : chlorophyll $a$ ratio of 0.4 , showed a $P_{\mathrm{m}}$ of $2.96 \times 10^{5} \mathrm{nmol} \mathrm{CO} 2(\mathrm{mg} \mathrm{chl} . a)^{-1} \mathrm{~h}^{-1}$ and an $I_{\mathrm{k}}$ of $280 \mu \mathrm{E} \mathrm{m}^{-2} \mathrm{~s}^{-1}$ (Fig. 1). Another batch culture of D. salina was grown in the laboratory under a constant illumination of $130 \mu \mathrm{E} \mathrm{m}^{-2} \mathrm{~s}^{-1}$. The light saturation curve indicated a considerable increase in $I_{\mathrm{k}}$ up to $540 \mu \mathrm{E} \mathrm{m}^{-2} \mathrm{~s}^{-1}$, with a lower $P_{\mathrm{m}}$ value of only $1.05 \times$ $10^{4} \mathrm{nmol} \mathrm{CO} 2(\mathrm{mg} \mathrm{chl} . a)^{-1} \mathrm{~h}^{-1}$, using a culture with a carotenoid : chlorophyll $a$ ratio of $1 \cdot 1$ (Fig. 1). The light saturation curve of $D$. salina collected from Solar Lake on the day of 


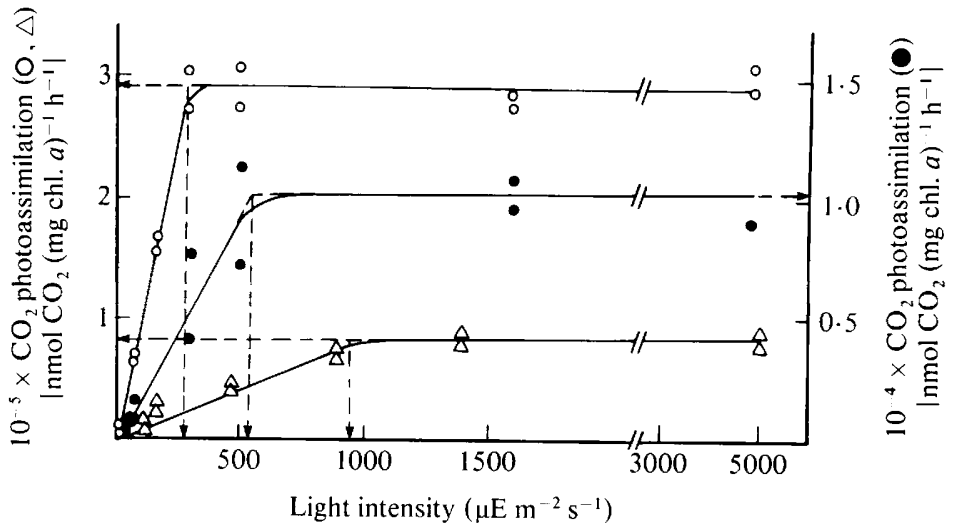

Fig. 1. Rate of oxygenic $\mathrm{CO}_{2}$ photoassimilation per $\mathrm{mg}$ chlorophyll $a$ of $D$. salina as a function of irradiation. Cells were collected in the exponential phase of growth in the laboratory or from the depth of maximum occurrence in Solar Lake. $\mathrm{NaH}^{14} \mathrm{CO}_{3}$ incorporation was carried out for $5 \mathrm{~min}$ at a specific light intensity. $\mathrm{O}$, Cells grown in the laboratory under $35 \mu \mathrm{E} \mathrm{m}^{-2} \mathrm{~s}^{-1} ; \mathrm{(right-hand} \mathrm{scale),} \mathrm{cells} \mathrm{grown}$ in the laboratory under $130 \mu \mathrm{E} \mathrm{m}^{-2} \mathrm{~s}^{-1} ; \triangle$, cells collected from Solar Lake. The $P_{\mathrm{m}}$ and $I_{\mathrm{k}}$ of each experiment are shown on the ordinate and abscissa, respectively, by the extrapolated dashed lines.

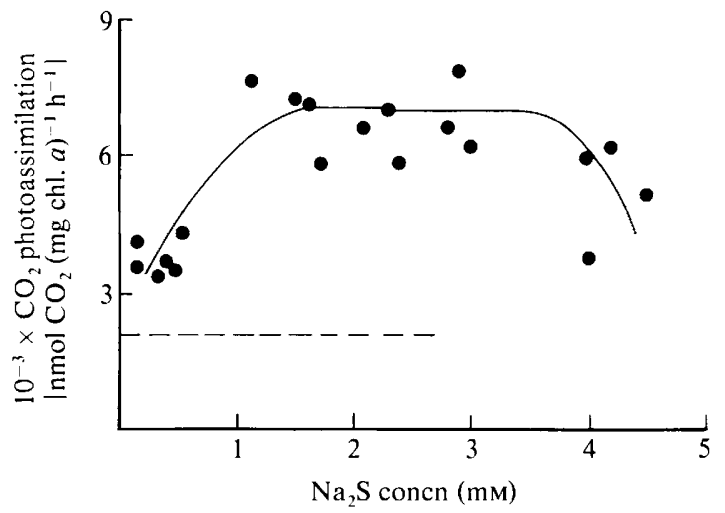

Fig. 2. Rate of anoxygenic $\mathrm{CO}_{2}$ photoassimilation per mg chlorophyll $a$ of $D$. salina as a function of $\mathrm{Na}_{2} \mathrm{~S}$ concentration. Cells were preincubated for $2 \mathrm{~h}$ under $\mathrm{Na}_{2} \mathrm{~S}$ and $5 \mu \mathrm{M}$-DCMU in the light before $\mathrm{NaH}^{14} \mathrm{CO}_{3}$ incorporation was carried out (for $5 \mathrm{~min}$ ). The broken line indicates the level of residual $\mathrm{CO}_{2}$ photoassimilation of cells which were incubated with $5 \mu \mathrm{M}-\mathrm{DCMU}$ in the absence of sulphide.

experimentation showed a linear increase in $\mathrm{CO}_{2}$ photoassimilation up to $860 \mu \mathrm{E} \mathrm{m}^{-2} \mathrm{~s}^{-1}$, and the $P_{\mathrm{m}}$ was $8.33 \times 10^{4} \mathrm{nmol} \mathrm{CO}_{2}(\mathrm{mg} \text { chl. } a)^{-1} \mathrm{~h}^{-1}$ (Fig. 1). The interpolated $I_{\mathrm{k}}$ value was $920 \mu \mathrm{E} \mathrm{m}^{-2} \mathrm{~s}^{-1}$ and the carotenoid : chlorophyll $a$ ratio was $1 \cdot 2$.

\section{Anoxygenic $\mathrm{CO}_{2}$ photoassimilation}

Figure 2 shows the $\mathrm{CO}_{2}$ photoassimilation of $D$. salina under different sulphide concentrations. An increase in $\mathrm{CO}_{2}$ photoassimilation was observed from $0.1 \mathrm{mM}-\mathrm{Na}_{2} \mathrm{~S}$ to $1 \mathrm{~mm}-\mathrm{Na}_{2} \mathrm{~S}$. Yet even at the latter sulphide concentration the $\mathrm{CO}_{2}$ photoassimilation rate was only $7.67 \times 10^{3} \mathrm{nmol} \mathrm{CO}_{2}(\mathrm{mg} \text { chl. } a)^{-1} \mathrm{~h}^{-1}$. In the sulphide range $1 \cdot 1-3 \mathrm{mM}-\mathrm{Na}_{2} \mathrm{~S}$ the rate was constant at $7.08 \times 10^{3} \mathrm{nmol} \mathrm{CO}_{2}(\mathrm{mg} \text { chl. } a)^{-1} \mathrm{~h}^{-1}$. Increasing the $\mathrm{Na}_{2} \mathrm{~S}$ concentration to 4 and $5 \mathrm{~mm}$ resulted in a considerable drop of $\mathrm{CO}_{2}$ photoassimilation to a minimum rate of $3.58 \times$ $10^{3} \mathrm{nmol} \mathrm{CO}(\mathrm{mg} \text { chl. } a)^{-1} \mathrm{~h}^{-1}$. The residual $\mathrm{CO}_{2}$ photoassimilation of D. salina under oxic conditions with the addition of DCMU was $38 \%$ of the maximum $\mathrm{CO}_{2}$ photoassimilation.

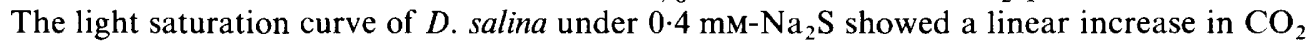
photoassimilation up to $250 \mu \mathrm{E} \mathrm{m}^{-2} \mathrm{~s}^{-1}$ (Fig. 3); the $P_{\mathrm{m}}$ was $5.67 \times 10^{3} \mathrm{nmol} \mathrm{CO} \mathrm{CO}_{2}(\mathrm{mg}$ 


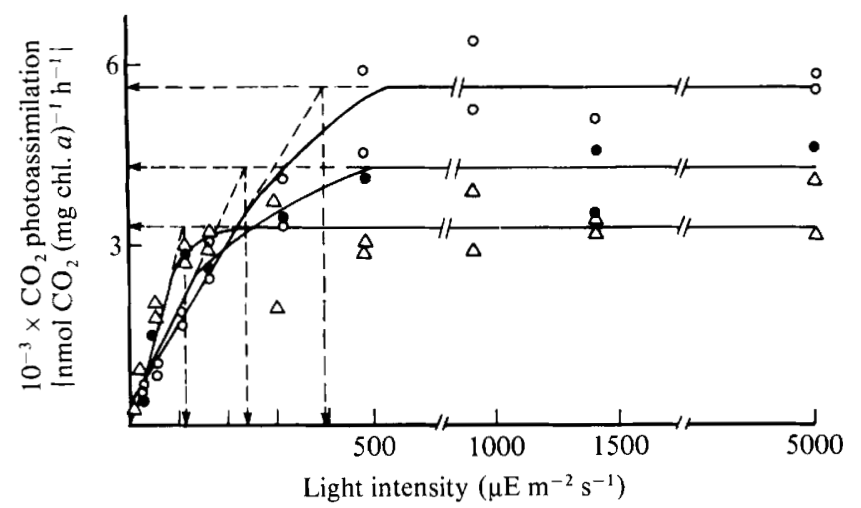

Fig. 3. Rate of anoxygenic $\mathrm{CO}_{2}$ photoassimilation per $\mathrm{mg}$ chlorophyll $a$ of $D$. salina as a function of irradiation. Cells were collected in the exponential phase of growth in the laboratory or from the depth of maximum occurrence in Solar Lake. Cells were preincubated under sulphide and DCMU for $2 \mathrm{~h}$ before addition of $\mathrm{NaH}^{14} \mathrm{CO}_{3}$. O Anoxygenic $\mathrm{CO}_{2}$ photoassimilation under $0.4 \mathrm{~mm}-\mathrm{Na}_{2} \mathrm{~S}$;

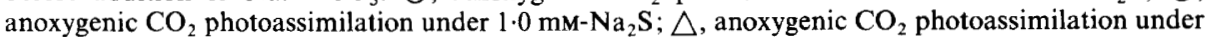
$1.2 \mathrm{~mm}-\mathrm{Na}_{2} \mathrm{~S}$. The $P_{\mathrm{m}}$ and $I_{\mathrm{k}}$ of each experimental condition are shown by the extrapolated dashed lines.

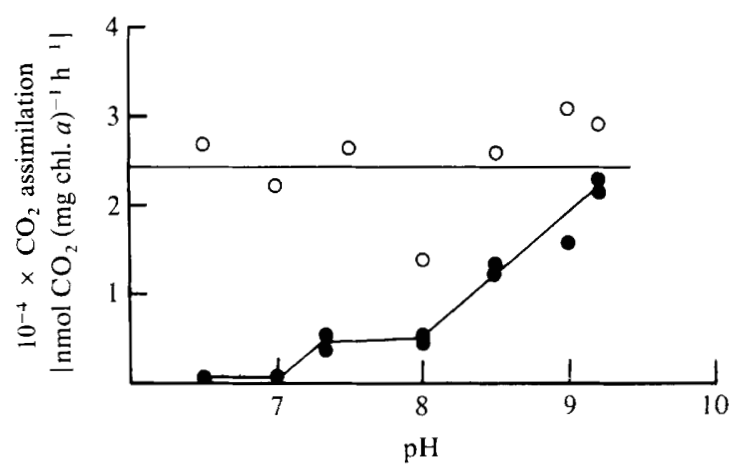

Fig. 4. Oxygenic (O) and anoxygenic (O) $\mathrm{CO}_{2}$ photoassimilation per mg chlorophyll $a$ of $D$. salina as a function of $\mathrm{pH}$. Up to $\mathrm{pH} 7.5$ cells were buffered with 1 mM-HEPES, and from $\mathrm{pH} 7.5$ and higher cells were buffered with $1 \mathrm{mM}$-Tricine.

chl. $a)^{-1} \mathrm{~h}^{-1}$, the $I_{\mathrm{k}}$ was $400 \mu \mathrm{E} \mathrm{m} \mathrm{m}^{-2} \mathrm{~s}^{-1}$, and the carotenoid : chlorophyll $a$ ratio was $0 \cdot 6$. Under $1.0 \mathrm{mM}-\mathrm{Na}_{2} \mathrm{~S}$ (Fig. 3) a linear increase in $\mathrm{CO}_{2}$ photoassimilation up to $150 \mu \mathrm{E} \mathrm{m}^{-2} \mathrm{~s}^{-1}$ was observed; the $P_{\mathrm{m}}$ was $4.58 \times 10^{3} \mathrm{nmol} \mathrm{CO}(\mathrm{mg} \mathrm{chl} . a)^{-1} \mathrm{~h}^{-1}$, the $I_{\mathrm{k}}$ was $240 \mu \mathrm{E} \mathrm{m}^{-2} \mathrm{~s}^{-1}$, and the carotenoid: chlorophyll $a$ ratio was 0.5 .

The anoxygenic $\mathrm{CO}_{2}$ photoassimilation of a natural population of $D$. salina was examined

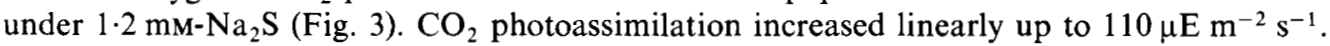
The $P_{\mathrm{m}}$ was $3.33 \times 10^{2} \mathrm{nmol} \mathrm{CO}(\mathrm{mg} \mathrm{chl} a)^{-1} \mathrm{~h}^{-1}$, the $I_{\mathrm{k}}$ was $120 \mu \mathrm{E} \mathrm{m}^{-2} \mathrm{~s}^{-1}$, and the carotenoid : chlorophyll $a$ ratio was $1 \cdot 2$.

\section{Effect of $p \mathrm{H}$ on aerobic and anaerobic $\mathrm{CO}_{2}$ photoassimilation}

The $\mathrm{CO}_{2}$ photoassimilation of $D$. salina was examined at different $\mathrm{pH}$ values under oxic and anoxic conditions (Fig. 4). Under oxic conditions the $\mathrm{CO}_{2}$ photoassimilation rate was constant over the $\mathrm{pH}$ range $6 \cdot 5-9 \cdot 2$. The average $\mathrm{CO}_{2}$ photoassimilation was $2.33 \times 10^{4} \mathrm{nmol} \mathrm{CO}_{2}(\mathrm{mg}$ chl. $a)^{-1} \mathrm{~h}^{-1}$. In a similar experiment under anoxic conditions $\left(1.2 \mathrm{~mm}-\mathrm{Na}_{2} \mathrm{~S}\right)$, no $\mathrm{CO}_{2}$ photoassimilation could be detected below $\mathrm{pH}$ 7. A steady increase in $\mathrm{CO}_{2}$ photoassimilation was measured at higher $\mathrm{pH}$ values, with a maximum rate of $2.25 \times 10^{4} \mathrm{nmol} \mathrm{CO}_{2}(\mathrm{mg}$ chl. $a)^{-1} \mathrm{~h}^{-1}$ at $\mathrm{pH} 9 \cdot 2$ (Fig. 4). Both experiments were carried out with the same culture of $D$. salina at a light intensity of $75 \mu \mathrm{E} \mathrm{m}^{-2} \mathrm{~s}^{-1}$. 


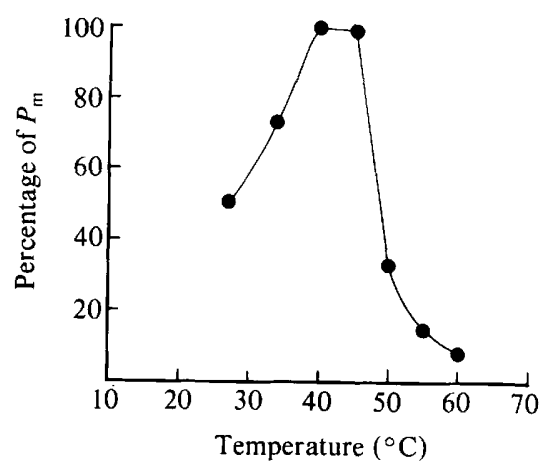

Fig. 5. Relative $\mathrm{CO}_{2}$ photoassimilation rate of a culture of $D$. salina at different temperatures. Cells were preincubated at the indicated temperature for $10 \mathrm{~min}$ prior to incubation with $\mathrm{NaH}^{14} \mathrm{CO}_{3}$ (for $30 \mathrm{~min}$ ).

\section{Effect of temperature on photosynthetic activity}

The photosynthetic activity of $D$. salina at different temperatures revealed a sharp optimum curve, with maximal $\mathrm{CO}_{2}$ photoassimilation activity at $40-45^{\circ} \mathrm{C}$ (Fig. 5). The temperature sensitivity was observed in short incubation periods of $30 \mathrm{~min}$.

\section{DISCUSSION}

Dactylococcopsis salina responded to different light intensities by increasing its $I_{\mathrm{k}}$ considerably with increasing light intensity. Growth under high light intensity also resulted in a decrease in the chlorophyll $a$ content and a consequent increase in the carotenoid :chlorophyll $a$ ratio. The adaptation to high light intensities was demonstrated by electron microscopy, which showed a marked decrease in the photosynthetic lamellae and cytoplasmic space (Fig. 6). Though the organism grows in situ under high light intensities, the $\boldsymbol{P}_{\mathrm{m}}$ of organisms grown under low light was considerably higher than that of organisms grown in the laboratory under high light intensities and that of organisms collected directly from Solar Lake.

Walsby et al. (1983) have shown that $D$. salina is found throughout the hypolimnion at the onset of stratification. With the buildup of mesothermy in Solar Lake (Cohen et al., 1977a), the distribution of $D$. salina is limited to the metalimnion. The light intensity at the peak of distribution is suboptimal yet the organism is well adapted to growth under those conditions. The adaptability of $D$. salina to growth at different light intensities is much more pronounced than that reported for other cyanobacteria and green algae (Table 1).

Dactylococcopsis salina appeared blue-green in colour when grown under low light intensities, becoming a deep orange colour when grown under high light intensities. This colour change is due to a drastic increase in the carotenoid : chlorophyll $a$ ratio, which suggests a protective role for carotenoids in the adaptation of the organism to high light intensity (Krinsky, 1966).

Since D. salina showed a considerable degree of adaptation to high light intensities, light cannot be the major limiting factor controlling its distribution.

Another possible environmental factor limiting the distribution of $D$. salina in Solar Lake is sulphide. Sulphide concentrations in the hypolimnion of Solar Lake build up to $3 \mathrm{~mm}$ (Cohen $e t$ $a l ., 1977 b$ ), yet $D$. salina was never found at sulphide concentrations higher than $10 \mu \mathrm{M}$. It was found to carry out anoxygenic photosynthesis under a broad range of sulphide concentrations $\left(0 \cdot 2-4.5 \mathrm{mM}-\mathrm{Na}_{2} \mathrm{~S}\right)$. The maximal rate of anoxygenic photosynthesis was comparable to the rates found by Garlick et al. (1977) for a variety of cyanobacteria. As expected, the toxicity of sulphide was pH dependent (Fig. 4), as was found by Hawsley \& Pearson (1979). The oxygenic photosynthesis, on the other hand, was unaffected by changes in $\mathrm{pH}$ from 6.5 to 9.2 . No anoxygenic photosynthesis could be recorded at $\mathrm{pH}$ values below 7. A steady increase of this activity was demonstrated with increasing $\mathrm{pH}$ values and the anoxygenic photosynthetic rate at pH $9 \cdot 2$ was similar to the oxygenic photosynthetic rate. This finding points to a $\mathrm{H}_{2} \mathrm{~S}$ sensitivity 

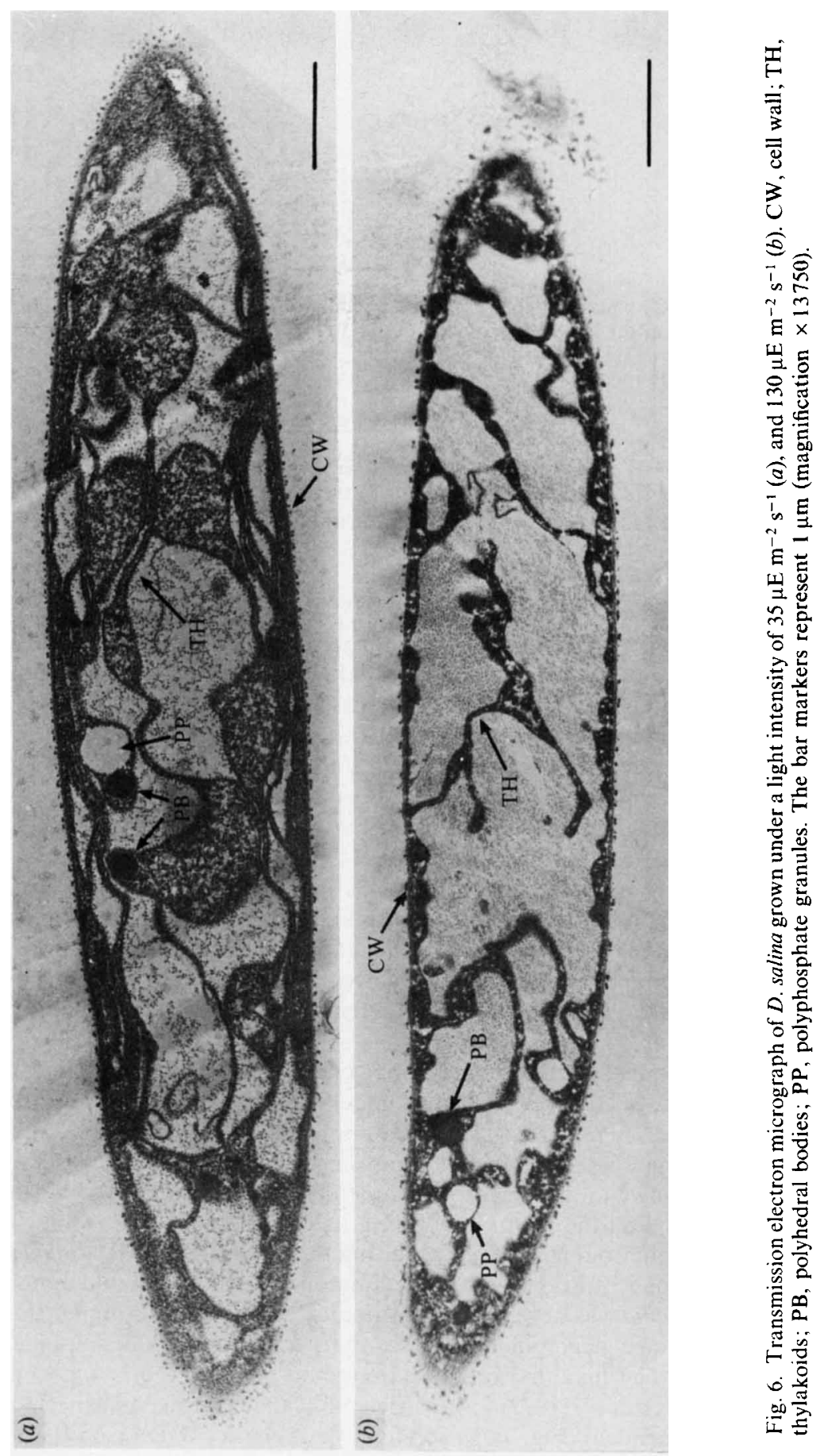
Table 1. $I_{\mathrm{k}}$ values obtained with cyanobacteria and green algae grown at different light intensities

The $I_{\mathrm{k}}$ values were interpolated by the present authors. Where possible, the light intensities were

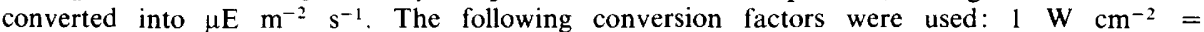
$1 / 40952 \mu \mathrm{E} \mathrm{m}^{-2} \mathrm{~s}^{-1} ; 1$ quantum $\mathrm{cm}^{-2} \mathrm{~s}^{-1}=1.47 \times 10^{15} \mu \mathrm{E} \mathrm{m}^{-2} \mathrm{~s}^{-1} ; 1$ foot-candle $=0 \cdot 1807 \mu \mathrm{E} \mathrm{m}^{-2} \mathrm{~s}^{-1}$.

\begin{tabular}{|c|c|c|c|c|}
\hline Organism & 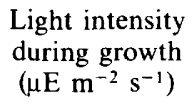 & $\begin{array}{c}\text { Temperature } \\
\text { during growth } \\
\left({ }^{\circ} \mathrm{C}\right)\end{array}$ & $\left(\mu \mathrm{E} \mathrm{m}^{-2} \mathrm{~s}^{-1}\right)$ & Author(s) \\
\hline \multicolumn{5}{|l|}{ Cyanobacteria } \\
\hline \multirow[t]{2}{*}{ Anacystis nidulans } & 10 & 30 & 200 & \multirow{2}{*}{$\begin{array}{l}\text { Vierling \& Alberte } \\
\text { (1980) }\end{array}$} \\
\hline & 100 & 30 & 300 & \\
\hline \multirow[t]{2}{*}{ Anacystis nidulans } & $80 \mathrm{~W}$ & 39 & 72 & \multirow{2}{*}{$\begin{array}{l}\text { Myers \& Kratz } \\
\text { (1955) }\end{array}$} \\
\hline & $960 \mathrm{~W}$ & 39 & 260 & \\
\hline \multirow[t]{2}{*}{ Synechococcus elongatus } & 50 & NG & 80 & \multirow[t]{2}{*}{ Jørgensen (1969) } \\
\hline & 500 & NG & 160 & \\
\hline \multirow[t]{3}{*}{ Dactylococcopsis salina } & 35 & 40 & 260 & \multirow[t]{3}{*}{ This paper } \\
\hline & 130 & 40 & 540 & \\
\hline & 1000 & $37-42$ & 920 & \\
\hline \multicolumn{5}{|l|}{ Green algae } \\
\hline \multirow[t]{2}{*}{ Chlorella vulgaris } & 11 & 20 & 22 & \multirow{2}{*}{$\begin{array}{l}\text { Steemann Nielsen } \\
\text { (1962) }\end{array}$} \\
\hline & 110 & 20 & 51 & \\
\hline \multirow[t]{2}{*}{ Scenedesmus obliquus } & 20 & 30 & 122 & \multirow{2}{*}{$\begin{array}{l}\text { Senger \& Fleishhacker } \\
\text { (1978) }\end{array}$} \\
\hline & 115 & 30 & 400 & \\
\hline
\end{tabular}

NG, Not given.

of $D$. salina. Since the in situ $\mathrm{pH}$ values at the depths of sulphide occurrence are around 7.5 (Cohen et al., 1977a), anoxygenic photosynthesis of $D$. salina cannot be significant. Furthermore, under these conditions even at low sulphide concentrations $\mathrm{H}_{2} \mathrm{~S}$ is toxic for $D$. salina.

Dactylococcopsis salina shows optimal photosynthetic activity at $40-45^{\circ} \mathrm{C}$, with a sharp drop in activity at higher and lower temperatures (Fig. 5). In situ measurements of photosynthetic activity were carried out on a natural population of $D$. salina collected from the peak distribution layer and later placed in light and shaded dialysis bags and incubated at various depths (Walsby et al., 1983). $\mathrm{CO}_{2}$ photoassimilation was inhibited in dialysis bags incubated both in the epilimnion - above peak distribution, at $25^{\circ} \mathrm{C}$ - and at the hypolimnion - below peak distribution, at $52{ }^{\circ} \mathrm{C}$. Inhibition of $\mathrm{CO}_{2}$ photoassimilation was observed in both the shaded and light dialysis bags, possibly ruling out photoinhibition as a major controlling environmental factor. Inhibition of $\mathrm{CO}_{2}$ photoassimilation at the epilimnion under low temperatures and at the hypolimnion under high temperatures coincided well with the temperature sensitivity of cultures of $D$. salina. Thus we conclude that vertical migration of the planktonic gas-vacuolated $D$. salina during the annual limnological cycle of Solar Lake is governed primarily by water temperature.

Professor A. E. Walsby (University of Bristol, U.K.) is thanked for stimulating discussions and advice. This work was supported by a grant from the Ministry of Science and Technology of the State of Niedersachsen, Federal Republic of Germany.

\section{REFERENCES}

CLINE, J. D. (1969). Spectrophotometric determination of hydrogen sulphide in natural water. Limnology and Oceanography 14, 454-458.

Cohen, Y., Padan, E. \& Shilo, M. (1975). Facultative anoxygenic photosynthesis in the cyanobacterium Oscillatoria limnetica. Journal of Bacteriology 123, 855-861.

Cohen, Y., Krumbein, W. E., GoldberG, M. \& ShILO, M. (1977a). Solar Lake (Sinai). 1. Physical and chemical limnology. Limnology and Oceanography 22, 597-608.

Cohen, Y., Krumbern, W. E. \& Shilo, M. (1977b).
Solar Lake (Sinai). 2. Distribution of photosynthetic microorganisms and primary production. Limnology and Oceanography 22, 609-620

Garlick, S., Oren, A. \& Padan, E. (1977). Occurrence of facultative anoxygenic photosynthesis among filamentous and unicellular cyanobacteria. Journal of Bacteriology 129, 623-629.

Hawsley, R. \& Pearson, H. W. (1979). pH dependent sulphide toxicity to oxygenic photosynthesis in cyanobacteria. FEMS Microbiology Letters 6, 287292.

JORGENSEN, B. (1969). The adaptation of plankton 
algae. 4. Light adaptation of different algal species. Physiologia plantarum 22, 1307-1315.

Jørgensen, B. B., Kuenen, J. G. \& Cohen, Y. (1979). Microbial transformation of sulfur compounds in a stratified lake (Solar Lake, Sinai). Limnology and Oceanography 24, 799-822.

KNOBLOCH, K. (1966). Photosynthetische Sulfidoxidation grüner Pflanzen. 1. Mitteilung. Planta 70, 73-86.

KRINSKY, N. J. (1966). The role of carotenoid pigment as protective agent against photosensitized oxidation in chloroplasts. In Biochemistry of Chloroplasts, vol. 1, pp. 423-430. Edited by T. W. Goodwin. London: Academic Press.

Myers, J. \& Kratz, W. A. (1955). Relations between pigment content and photosynthetic characteristics in a blue-green alga. Journal of General Physiology 39, $11-22$.

NaKamura, H. (1937). Über das Auftreten des Schwetelkügelchens im Zellinneren von einigen niederen Algen. Botanical Magazine 51, 529-533.

NaKamURA, H. (1938). Über die Kohlensaureassimilation bei niederen Algen in Anwesenheit des Schwefelwasserstoffs. Acta phytochimica 10, 271-281.

Oren, A., Padan, E. \& Avron, M. (1977). Quantum yields for oxygenic and anoxygenic photosynthesis in the cyanobacterium Oscillatoria limnetica. Proceedings of the National Academy of Sciences of the United States of America 74, 2152-2156.

Senger, H. \& FleishHacker, P. H. (1978). Adaptation of the photosynthetic apparatus of Scenedesmus obliquus to strong and weak light conditions. 1. Difference in pigments, photosynthetic capacity, quantum yields and dark reactions. Physiologia plantarum 43, 35-42.

Stanier, R., Kunisawa, R., Mandel, M. \& CohenBAzIRE, G. (1971). Purification and properties of unicellular blue green algae (order: Chroococcales). Bacteriological Reviews 35, 171-205.

SteEMANN Nielsen, E. (1962). Inactivation of the photochemical mechanism in photosynthesis as a means to protect cells against too high light intensities. Physiologia plantarum 15, 161-171.

Stewart, W. D. P. \& Pearson, H. W. (1970). Effects of aerobic and anaerobic conditions on growth and metabolism of blue-green algae. Proceedings of the Royal Society B175, 293-311.

Strickland, J. D. \& Parsons, T. R. (1968). A Practical Handbook of Seawater Analyses. Bulletin of the Fisheries Research Board of Canada no. 167.

Talling, J. F. (1957). Photosynthetic characteristics of some freshwater diatoms in relation to underwater radiation. New Phytologist 56, 1-32.

Vierling, E. \& Alberte, R. S. (1980). Functional organization and plasticity of the photosynthetic unit of the cyanobacterium Anacystis nidulans. Physiologia plantarum 50, 93-98.

Walsby, A. E., Cohen, Y.\& Van RiJn, J. (1983). The biology of the cyanobacterium Dactylococcopsis salina nov. sp. Proceedings of the Royal Society, Series $B$ (in the Press). 